\begin{tabular}{|c|c|c|}
\hline \multirow[b]{2}{*}{$8 C$} & $\begin{array}{l}\text { International Journal of Current Research in } \\
\text { Biosciences and Plant Biology }\end{array}$ & \\
\hline & Volume $5 \bullet$ Number 6 (June-2018)・ISSN: 2349-8080 (Online) & \\
\hline $\begin{array}{l}\text { EXCELLENT } \\
\text { PUBLISHERS }\end{array}$ & Journal homepage: www.ijcrbp.com & 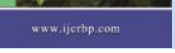 \\
\hline
\end{tabular}

\title{
The Influence of Cempedak (Artocarpus champaden Lour.) Ripening Variation on Organoleptic Properties of Jam Produced
}

\author{
Dwi Nur Aini Dahlan* \\ Lecture Staff, Teacher Training Science Program at Islamic State Institute, Samarinda 752521, \\ East Kalimantan, Indonesia \\ ${ }^{*}$ Corresponding author.
}

\begin{tabular}{|c|c|}
\hline Art & B S T \\
\hline & \multirow{4}{*}{$\begin{array}{l}\text { Cempedak (Artocarpus champaden Lour.) is a tropical fruit plant of the Moraceae } \\
\text { family, which has a high economic value and become a popular fruit by the } \\
\text { community. To suffice the great demand for cempedak fruit, it is necessary to fruit } \\
\text { ripening technology both in traditional ways (leaves) and non-traditional ways } \\
\text { (carbide). To increase the sale value of cempedak fruit through ripening technology } \\
\text { can be continued processing into jam. The purpose of this research is to know the } \\
\text { right type of ripening in producing good cempedak jam. The work method in this } \\
\text { research consists of two stages are cempedak ripe and Jam making. Data analysis } \\
\text { using RDC (Random Design Complete) with ANOVA. Using } 4 \text { treatments (regular } \\
\text { plain, dapdap leaves, gamal leaves and carbide) was repeated } 3 \text { times. Continued } \\
\text { with Organoleptic Test using } 20 \text { panelists who assess: a. Flavor b. Aroma c. Color d. } \\
\text { Texture. Rating scale: } 1 \text { = Very dislike } 2 \text { = Do not like } 3=\text { likes } 4 \text { = Very like. The } \\
\text { results with data analysis showed that there was no significant effect of varieties of } \\
\text { ripening on the flavour of cempedak jam and there was a significant influence of } \\
\text { varieties of ripening to the aroma, color and texture of cempedak. Ordinary ripening } \\
\text { has the flavor and aroma of cempedak jam most favored by the panelists. The } \\
\text { ripening of carbide has the color and texture of cempedak jam most favored by the } \\
\text { panelists. }\end{array}$} \\
\hline & \\
\hline Key & \\
\hline nology & \\
\hline
\end{tabular}

\section{Introduction}

Cempedak (Artocarpus champaden Lour.) is a tropical fruit plant of the Moraceae family, which has a high economic value. Cempedak fruit became one of the many popular people favored because it has a distinctive flavour, aroma and shape and nutritional content is high enough (Tetty, 2011). The results of Leong and Sui (2002) cempedak contains antioxidant content of $126 \pm 19.1 \mathrm{mg} / 100$ $\mathrm{g}$ and classified as fruits with medium antioxidant content (70-200 mg / $100 \mathrm{~g}$ ). Cempedak fruit is included in climatisic fruit, commonly harvested still raw and cooked after storage. To suffice the 
great demand for cempedak fruit, required ripening technology in uniform fruit maturity.

Horticultural ripening is an action performed to accelerate the process of ripening fruit by storing the fruits that have been picked on certain harvest periode in a relatively closed place. The ripening only succeeds in accelerating the maturation of the climacteric fruit group (Writer Team, 1998). According Kaleka (2013), the immature fruit when harvested still keeps the physiological process by producing ethylene gas and carbon dioxide in increasing amounts until fruit ripening process occurs.

Various ways of ripening fruits those have been done in a traditional way using leaf and nontraditional using carbide. Suryanegara (2012) study shows gamal leaves and dapdap leaves takes 3-4 days to ripen fruit and both are very environmentally friendly, natural and sweet aroma. These leaves produce ethylene gas which stimulates the ripening of the fruit. The results of research Arif et al. (2014) showed that the ripening with carbide can accelerate the cempedak fruit ripening faster than the leaves. Wardani et al. (2014) 1 gof carbide produces $349 \mathrm{ml}$ of acetylene to be used in the maturation system by replacing the ethylene gas produced directly by the fruits.

To increase the value of cempedak fruit through ripening technology can be continued processing into jam. Jam is a thick or semi-solid food product made from a blending fruit and sugar. Good jam should be brightly colored, thick, and has the original fruit flavor (Margono, et al., 1993). Another very important benefit of making jam is a proper post-harvest handling to increase the sales that can be offered into a typical modern food of Borneo. East Kalimantan is one of the largest cempedak producing provinces in Indonesia. It is also very helpful for cempedak farmers when it comes to the peak of the harvest season. Based on the description will be done a research about the effect of ripening variation on cempedak jam which includes aroma, aroma, color and texture.

Based on the background that has been described, there will be research to see the effect of variation of cempedak ripening type to organoleptic jam produced. The purpose of this research is to know the right type of ripening to produce good cempedak jam, with organoleptic test on flavor, aroma, color, and texture.

\section{Materials and methods}

\section{Fruit cempedak ripening}

The way to do the cempedak ripening is 1 . Prepared cardboard as a ripening place 2 . Cempedak fruit and the material is inserted into the box including gamal leaf, dapdap leaf and carbide 3. Cardboard closed tightly and wait until the limit of 7 days.

\section{How to make jam}

The way in making the jam is 1 . Prepared material in the form of cempedak fruit, sugar, and citric acid. 2. Cempedak fruit peeled with a knife. 3. Materials weighed (cempedak $150 \mathrm{~g}$, sugar $1.5 \mathrm{~g}$, citric acid 1 g) 4. Cempedak fruit washed with water so that the dirt that is still attached or mixed between the flesh can be cleaned. 5. Cempedak flesh blanched in the temperature of $60-80^{\circ} \mathrm{C}$ for 5 minutes. 6 . Using a knife, the cempedak bacon is cut into small pieces. 7. Cempedak fruit that has been cut is blended until it becomes mush. 6. Cempedak flesh cut into small pieces with a knife. 7. Cempedak fruit that has been cut is blended until it becomes slurry.8. Cempedak slurry is put into the pan and then added with sugar $(150 \mathrm{~g})$, during the cooking process, the cempedak slurry is stirred constantly until it becomes thick and the color turns to brown. After the slurry is brown, cempedak dough is mixed with citric acid (1 g) and stirred until evenly distributed. 9. When the cempedak dough is thick, the pan is lifted and cooled. 10. The cooled cempedak jam is put into a sterilized bottle (10 minutes - 15 minutes). 11. Jam cempeda ready (ready made).

\section{Data analysis}

Data analysis from this research using RDC (Random Design Complete) with one way anova. 
Using 4 treatments (Factor A). Each treatment was repeated 3 times. Factor $\mathrm{A}$ is a type of cempedak fruit ripening consisting of: $\mathrm{A} 0=$ regular cempedak ripening. $\mathrm{A} 1=$ cempedak ripening with gamal leaves. $\mathrm{A} 2=$ cempedak ripening with dapdap leaves. A3 = cempedak ripening with carbide

\section{Organoleptic test}

In this study the panelist preferences will be tested through organoleptic tests. The panelists used are 20 people, namely panelists who are not trained with assessment criteria include: a. Flavor b. Aroma c. Color $\mathrm{d}$. Texture. scale rating: $1=$ Very dislike 2 $=$ Dislike $3=$ Likes $4=$ Very likes.

\section{Results}

\section{The influence of cempedak ripening variation type to the jam flavour}

Table 1 shows the significance value of ANOVA 0.284 greater than 0.05 which means no flavour difference produced by cempedak jam based on variations of fruit ripening type. The average flavor generated by the variation of the ripening type can be seen in Fig. 1.

Fig. 1 shows that the control is most favored by panelists, the average number is 58.67. The dapdap leaf ripening was favored secondly by panelists with an average of 57.67, followed by ripening using a kabide of 56.67. The flavour that is slightly favored by the panelists is the flavour produced by cempedak fruit using gamal ripening of 54.33. the most favored jam by the panelists is the jam that the usual cempedak ripening fruit. This is because the process of ripening fruit is accompanied by a process of alteration of starch is perfect. Erna (2016) adding a perfect alteration of starch substances will optimize the formation of organic acids.

The content of starch that is still a complex carbohydrate is converted by enzyme amylase into monosakarida that is easily digested. The acid molecule will be changed to be neutral by the enzyme kinase. According to Jacobs in Herawati
(2011) starch is a carbohydrate which is a glucose polymer, and consists of amylose and amylopectin. Starch on food is found in starch granules. Starch may experience gelatination and retrogradation. Both of these conditions are highly determined by temperature, water content, ph, starch concentration of granular type and starchy heterogeneity.

\section{The influence of cempedak ripening variation type to the jam aroma}

Table 2 shows an ANOVA 0.000 significance value less than 0.05 which means there is a noticeable difference of aroma produced by cempedak jam based on variations of fruit ripening type. The average aroma produced by the variation of ripening type can be seen in Fig. 2 .

The average data obtained from aroma calculations can be seen that the variation of cempedak ripening can give a difference to the aroma of the jam produced. Ripening with control has the highest average scent value favored by panelists of 60 . Furthermore with the average value of the second great aroma is by using dapdap leaves of 59.33. Cempedak ripening using dapdap leaves is also very different from ripening using gamal leaf. The next average score of 56 by ripening using gamal leaves. cempedak ripe with gamal leaf is very different aroma with the control but not significantly different with dapdap leaves. The least favored aroma of panelist is the cempedak fruit jam whose fruit is consumed by using carbide as much as 53. Cempedak ripening using carbide is very different from other treatments.

The aroma of jam from fruit ripening using carbides is least preferred by the panelists. This is because the ripening of the fruit has formed volatile compounds (aromatic emissions) did not take place optimally. Volatile compounds become gases when there is an increase in temperature. If the volatile compounds evaporate then the component will decrease the quality. The molecular weight of the volatile compound can be measured based on the measurement of the vaporization gas period (Stoker, 1993). 
The physiological changes that occur in the maturation process by ethylene are affecting the climateric respiration that ethylene affects membrane permeability, so that cell permeability becomes large, it results in faster respiratory metabolism (Zaharah et al., 2013). Due to the enlargement of the cell wall is the absorption of water from the rising peripheral which is usually through osmosis or diffusion process. Mulyawanti et al. (2006) added that more water contained in fruit ripening causes compounds that contribute to less acidic scents and volatile compounds. At least volatile compounds in the fruit can also be damaged and lost due to heat. it also causes the least favorable aroma of jam produced from carbide carbide because it can produce heat.

\section{The influence of cempedak ripening variation type to the jam color}

Table 3 shows the significance value of ANOVA 0.000 is smaller than 0.05 which means there is a significant difference of color produced by cempedak jam based on variation of fruit cultivation type. The average color produced by the variation of the ripening type can be seen in Fig. 3 .

Based on the result of 5\% BNT test showed that the cempedak ripening using gamal and dapdap leaves was not significantly different with the control but very different from the carbide. The average data obtained from the color calculation can be seen that the variation of cempedak ripening can give a difference color of the jam produced. Cempedak ripening using dapdap leaves has a smallest average value of the color of 47.67. Furthermore, the method of ripening with the control has a mean value of the color is 51.33. The next average value of ripening using gamal leaves is 51.67. The most preferred color is ripening using a carbide having an average of 66 and the least preferred by the panelist is the cempedak jam whose fruit is riped using dapdap leaves.

Based on the results of observations that have been done, it can be seen that the most preferred color of cempedak jam by the panelist is the cempedak jam whose fruit is riped using carbide. Winarno (2002) states that food color plays an important role in the acceptance of food because color can provide clues about chemical changes in the food during processing.

Apandi (1984) adds a statement that the color of the fruit is influenced by certain pigments, such as carotenoid pigments and flavonoids. This pigment occurs after the degradation of chlorophyll, which then causes change of the fruit color from greenish to yellowish. This color change occurs after the fruit reaches the climacteric stage, followed by a change in texture. This implies that the carbide has the highest acetyl content than the jams consumed using gamal leaves, dapdap leaves and without ripening. The high content of acetylene having a chemical structure is similar to that of natural ethylene which accelerates respiration and fruit metabolism, but there is no forming of anthocyanin pigment during treatment with ripening stimulants (Pratt and Reid, 1976). Ethephon or ethrel can accelerate the degradation of chlorophyll in bananas, mangoes and oranges. Actual ethrel addition can also increase skin color, total dissolved solids and vitamin $\mathrm{C}$ fruit (El Rayes, 2000).

\section{The influence of cempedak ripening variation type to the jam texture}

Table 4 shows an ANOVA 0.000 significance value less than 0.05 which means there is a significant difference in the texture produced by cempedak jam based on variations of fruit ripening type. The average texture generated by the variation of the ripening type can be seen in Fig. 4.

The average data of the color calculation can be seen that the variation of cempedak ripe can give a difference to the texture of jam. Ripening type using dapdap leaves and gamal leaves both have the smallest average color values of 52.33 so that both are no different. Next the ripening by the control method has a mean value of texture is 58 and it has a significant difference with all treatments. 
Table 1. ANOVA test of cempedak jam flavor.

\begin{tabular}{llllll}
\hline & Sum of Squares & df & Mean Square & F & Sig. \\
\hline Between Groups & 31.000 & 3 & 10.333 & 1.512 & 0.284 \\
Within Groups & 54.667 & 8 & 6.833 & & \\
Total & 85.667 & 11 & & & \\
\hline
\end{tabular}

Table 2. ANOVA test of cempedak jam aroma.

\begin{tabular}{llllll}
\hline & Sum of Squares & df & Mean Square & F & Sig. \\
\hline Between Groups & 94.250 & 3 & 31.417 & 23.563 & 0.000 \\
Within Groups & 10.667 & 8 & 1.333 & & \\
Total & 104.917 & 11 & & & \\
\hline
\end{tabular}

Table 3. ANOVA test of cempedak jam color.

\begin{tabular}{llllll}
\hline & Sum of Squares & df & Mean Square & F & Sig. \\
\hline Between Groups & 589.667 & 3 & 196.556 & 23.124 & 0.000 \\
Within Groups & 68.000 & 8 & 8.500 & & \\
Total & 657.667 & 11 & & & \\
\hline
\end{tabular}

Table 4. ANOVA test of cempedak jam texture.

\begin{tabular}{llllll}
\hline & Sum of Squares & df & Mean Square & F & Sig. \\
\hline Between Groups & 188.917 & 3 & 62.972 & 20.991 & 0.000 \\
Within Groups & 24.000 & 8 & 3.000 & & \\
Total & 212.917 & 11 & & & \\
\hline
\end{tabular}

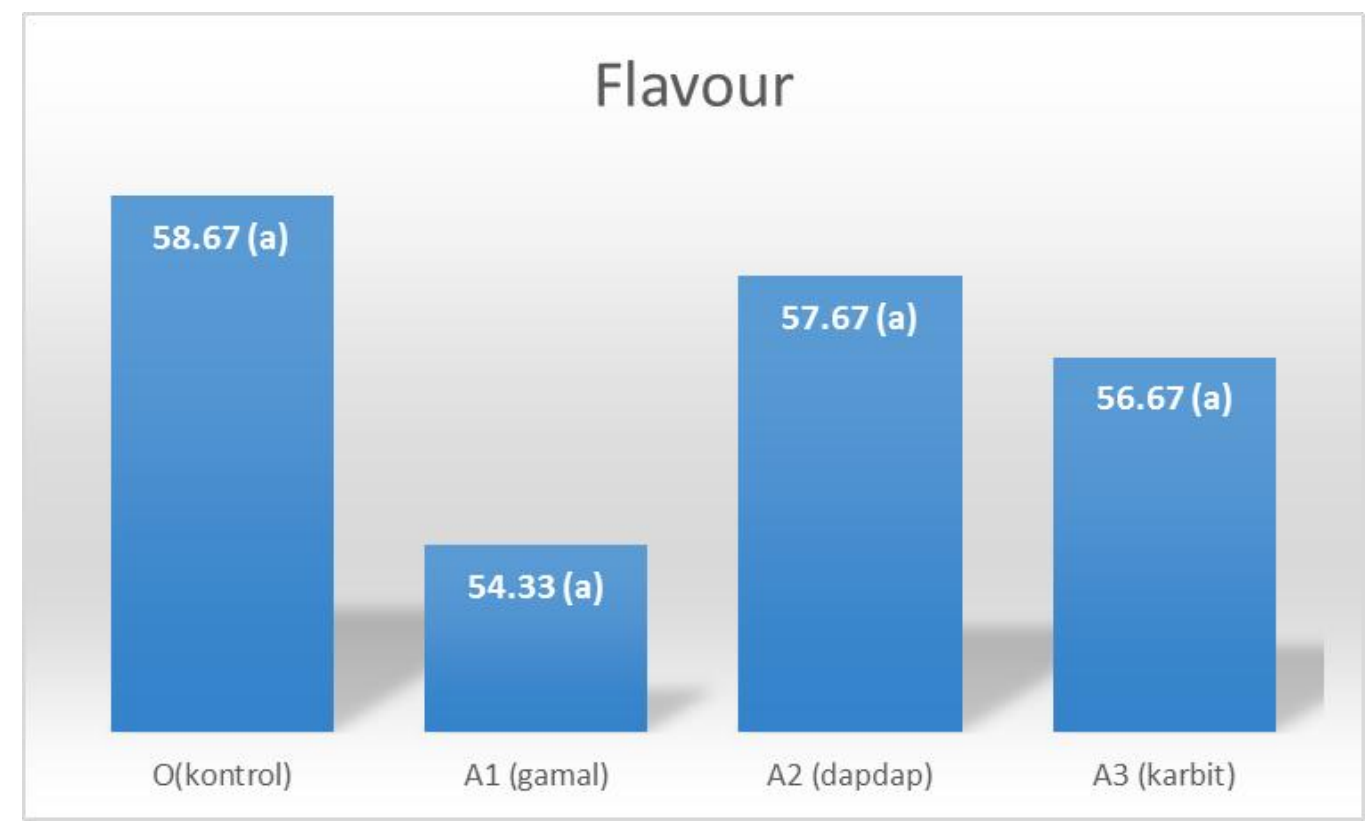

Fig. 1: Average flavor generated by variations of ripening type. 


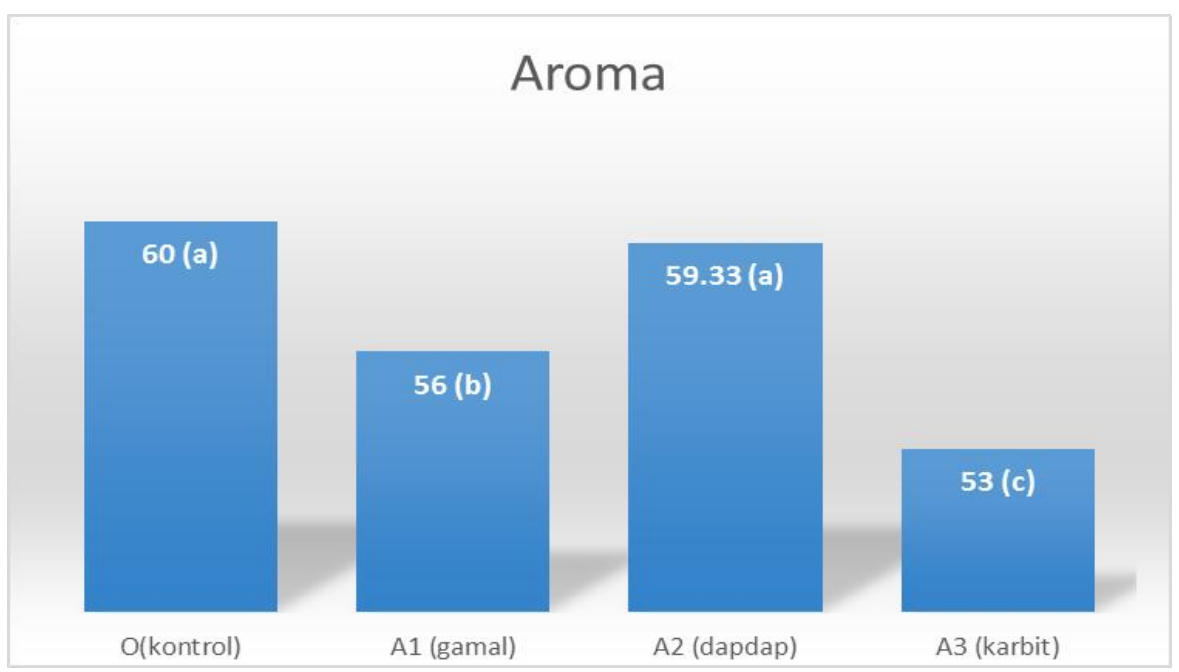

Fig. 2: Average aroma generated by variations of ripening type.

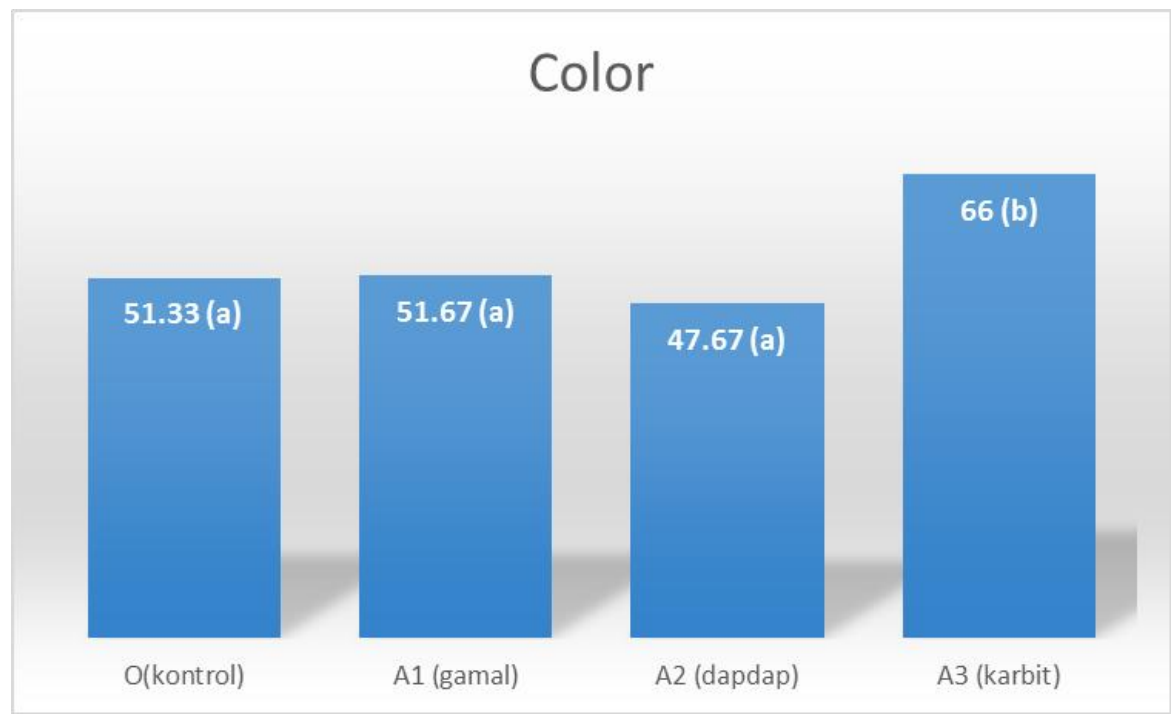

Fig. 3: Average colors produced by variations of ripening type.

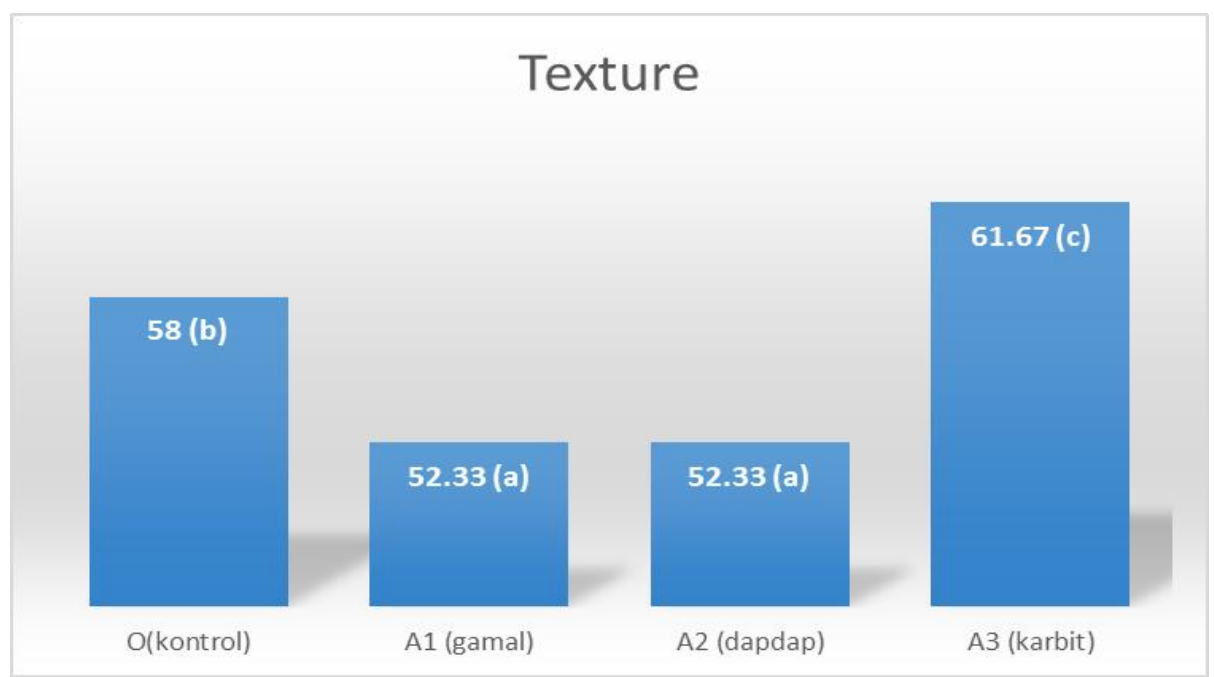

Fig. 4: Average texture generated by variations of ripening type. 
Next average score is 61.67 from ripening method by using carbide which is significantly different from all treatments, thus the most preferred texture by the panelists is ripening by using carbide. The least favored texture by panelists is cempedak ripening using gamal leaves and dapdap leaves.

The jam texture from fruit ripening with carbide is most favored by the panelists as it produces a soft, evenly mild texture. Ethylene greatly affects the permeability of the membrane, so the cell permeability becomes large, it result on softening of the cell wall which is the structural component that surrounds each plant cell so that respiratory metabolism is faster (Zaharah et al., 2013). Cell walls have plastic properties. The cell contents of the fruit can be enlarged by absorbing water from its surroundings normally through osmosis and diffusion processes.

Therefore turgor pressure can affect cell hardness and result in level of hardness in fruit (nopianto, 2007). This is in compatible with Zhang et al. (2012) research suggests that using ripening material (ethepon) ingredients may affect the kiwi fruit hardness levels beginning two days after ripening.

Rupinder et al. (2007) states that the use of ethrel causes softening of the fruit and accelerates the maturation of some fruits. Furthermore, according to Rahman and Shintawati (2014) that the content of pectin substances in the fruit will affect fruit hardness. During the fruit ripening process, the pectin substances will be hydrolyzed into soluble components so that the total pectin substance will decrease and the water-soluble component will increase and cause the fruit to soften. The more mature the fruits then the level of hardness decreases, while the young fruit has a higher level of hardness.

\section{Conclusion}

The conclusion in this study is the flavour and aroma of cempedak jam most preferred by the panelists is from ordinary ripening. Most preferred by the panelists of the color and texture of cempedak jam which is from ripening method by using carbide.

\section{Conflict of interest statement}

Author declares that there is no conflict of interest.

\section{References}

Apandi, M., 1984. Fruit and vegetable technology, Bandung: Alumni.

Arif, Abdullah, B,. Wahyu Diyono, Enrico Syaefullah, Suyanti., Setyadjit., 2014. Optimalization of cempedak ripening (Artocarpus champeden). Agric. Informat. 23 (1), 35-46.

El Rayes, D. A., 2000. Enhancement of colour development and fruit ripening of Washington neven and amoon oranges by ethrel pre-harvest applicartion. Assiut. J. Agric. Sci. 31(2), 71-87.

Erna, L., 2016. The Influence of Dose Carbide $(\mathrm{CaC} 2)$ and the Type of Packaging to the Quality of Bananas Ambon. Thesis. Departemen of Agrotechnology at Collage of Agriculture Lampung.

Herawati, H., 2011. Potential in the development of starch resistant products as functional food. J. Agric. Res. 30 (1),

Kaleka, N. 2013. Commercial Bananas. Arcita Publisher. Surakarta. First edition.

Leong L. P dan G. Shui. 2002. An Investigation Of Antioxsidant Capacity of Fruit in Singapore Markets. Food Chemistry. 76: 69-75

Margono, Tri. et al., 1993. Food technology women information center in development.http: //iptek.net.id, accessed on 20 March 2018

Mulyawanti et al, 2006.Aflatoxin in corn and its prevention. Agricultural post harvest technology Bulletin vol 2.

nopianto, E. 2007. Practical engineering report storage and warehousing of intact fruits. Dept TIN, fateta, IPB, Bogor.

Pratt dan Reid, 1976. The tamarillo: Fruit growth and maturation, ripening, respiration, and the role of ethylene. J. Sci. Food Agric. 27, 399404. 
Rahman, F., Shintawati, A. R., 2014. Effect of gamal (Gliricidia sepium) Leaves extract for immersing process of kepok Banana (Musa balbisiana) on chemical and sensory characteristic after ripening process. J. Agric. Technol. Univ. Muawarman. 9(2), 75-81.

Rupinder, S., Poorinima, S., Pathak, N., Singh, V. K., Dwivedi, U. N., 2007. Modulation of mango ripening by chemicals: Physiological and biochemical aspects. Plant Growth Regul. 53, 137-145.

Stoker, H.S., 1993. Introduction to Chemical Principles. Macmillan Publishing Company, New York.

Suryanegara, 2012.Traditional Fruit Diving Using Gamal Leaf (Glircidia maculata), Dapdap, Gerombong and Carbit. http:// wayansuryanegara.blogspot.co.id/2012/04/peng eraman-buah-secara tradisional.html. accessed on 20 March 2018.

Tetty, N.A.H., 2011. The influence of comparative concentration of sucrose and cempedak juice
(Artocarpus integer (Tunb.) Merr.) on quality of candy jelly during on storage periode (Essay). Faculty of Technobiology of Biology Program. Atma Jaya University Yogyakarta.

Wardani, K. E., Mantiri, F.R., Song Ai N., Rumondor, M., 2014. Study of ethylene triple response on the seedlings of three varieties of soybean. Boislogos J. 4 (2).

Winarno, F. G., 2002. Food Chemistry and Nutrition. PT Gramedia, Jakarta.

Writer Team, P.S., 1998. Agribusiness of Fruit Plants. Jakarta: Niaga Swadaya. ISBN 97948919.

Zaharah, S.S., Singh, Z. ., Symons, G.M., Reid, J.B., 2013. Mode of action of abscisic acid in triggering ethylene biosynthesis and softening during ripening in mango fruit. Postharv. Biol. Technol. 75, 37-44.

Zhang, I., Li, S., Liu, X., Song, C., Liu, X., 2012. Effects of ethephon on physicochemical and quality properties of kiwifruit during ripening. Postharv. Biol. Technol. 65, 69-75.

\section{How to cite this article:}

Aini Dahlan, D. N., 2018. The influence of cempedak (Artocarpus champaden Lour.) ripening variation on organoleptic properties of jam produced. Int. J. Curr. Res. Biosci. Plant Biol. 5(6), 58-65.

doi: https://doi.org/10.20546/ijcrbp.2018.506.006 